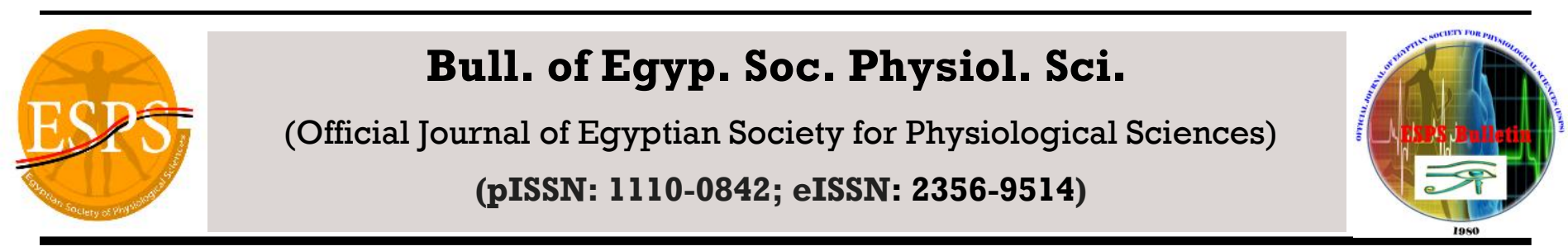

\title{
The Potential Protective Effects of Tetrahydrobiopterin on Cadmium- Induced Pancreatic Changes in Male Rats
}

\section{Ebtihal Anwar Abd EL-Aziz and Nashwa Aly Abd El-Mottaleb}

Received: 29,Oct, 2015

Accepted: 16, Dec, 2015

Available online: 25, Dec, 2015

\section{Keywords}

- Tetrahydrobiopterin,

- Cadmium,

- Inflammation,

- Oxidative Stress

Department of Physiology. Faculty of Medicine. Assiut University. Egypt.

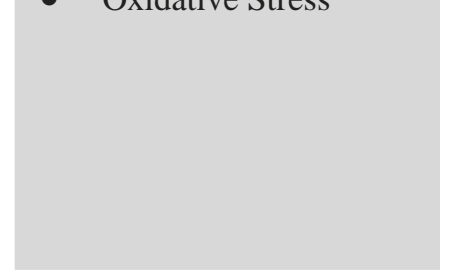

\begin{abstract}
Cadmium $(\mathrm{Cd})$ is a widespread environmental and industrial pollutant. It accumulates in the pancreas and could influence its endocrine and exocrine functions. Tetrahydrobiopterin (BH4) is essential for various processes, and present in all tissues of higher organisms. This study was designed to investigate the effect of $\mathrm{BH} 4$ on the acute pancreatic damage induced by $\mathrm{Cd}$ and detect its mechanism(s) of action. Thirty rats were randomly divided into three groups (10 rats each). Control: received saline, $\mathrm{Cd}$ : received (single dose of $\mathrm{CdCl} 24 \mathrm{mg} / \mathrm{kg}$, i.p.) and $\mathrm{BH} 4+\mathrm{Cd}$ : received (single dose of BH4 $20 \mathrm{mg} / \mathrm{kg}$, i.p.) one hour before single dose of $\mathrm{CdCl}_{2}$ (4 mg/kg, i.p.). The $\alpha$-amylase, lipase, glucose, insulin and interleukin 6 (IL-6) levels were measured in serum and intercellular adhesion molecule-1(ICAM-1), malondialdehyde (MDA) and superoxide dismutase (SOD) levels were measured in pancreatic homogenate. Histopathological examination of pancreas was done. BH4 improved pancreatic functions, where $\alpha$-amylase, lipase, glucose and IL-6 levels were significantly decreased while insulin levels were significantly increased in serum. Pancreatic damage was ameliorated as evident by significant decrease of ICAM-1 and MDA and significant increase of SOD levels in pancreatic homogenate. Also, the disturbed pancreatic tissues were ameliorated. In conclusion, BH4 induced improvements in pancreatic tissue and functions in cadmium-exposed rats. Part of BH4 beneficial effects could be attributed to anti-oxidative and anti-inflammatory activity.
\end{abstract}

Corresponding author: Nashwa Aly Abd El-Mottaleb, Department of Medical Physiology, Faculty of Medicine, Assuit University, Assuit, Egypt. phone: +201223971492; email: nashwa_ali1@ @otmail.com 


\section{INTRODUCTION}

Cadmium (Cd) is one of the widely used heavy metals and implicated in many industrial applications like electric batteries, electronic components, pigment, and fertilizer and considered as environmental pollutant [1]. Major sources of cadmium exposure include the diet, in particular rice, cereals, potatoes, and other root vegetables, and also smoking as cadmium in tobacco smoke is effectively absorbed in the lungs [2]. It accumulates in various organs, the kidneys, liver, testes, pancreas, thyroid, salivary glands, bone and central nervous system [3].

Cadmium could influence both endocrine and exocrine functions of pancreas [4]. Also, it leads to necrosis, degeneration and degranulation of beta cells causing an increase in serum glucose level [5]. The initial acinar cell damage in the early stage of acute pancreatitis of any etiology is caused by a hypersecretion of pancreatic proteolytic enzymes [6]. Cadmium induces tissue injury through creating oxidative stress and decreasing the biological activities of some antioxidant enzymes [7]. In addition, it can cause release of inflammatory mediators and enhance expression of adhesion molecules that initiate a cascade of cellular and humoral responses leading to inflammation [8].

Tetrahydrobiopetrin (BH4) is present in probably every cell or tissue of higher organisms and plays a key role in a number of biological processes and pathological states associated with monoamine neurotransmitter formation, cardiovascular and endothelial dysfunction, the immune response and pain sensitivity [9]. BH4 is biosynthesized from guanosine triphosphate (GTP) [10]. BH4 is an essential cofactor for all three nitric oxide synthase (NOS) isoforms (endothelial, neuronal, and inducible), aromatic amino acid hydroxylases, and alkylglycerol monooxygenase $[11,12]$. Also, It is involved in the biosynthesis of neurotransmitters, including epinephrine, norepinephrine, dopamine, and serotonin [13].

Tetrahydrobiopterin improved the NO-mediated endothelial function in patients with vascular disease states, such as hypercholesterolaemia [14], Type 2 diabetes [15] and overt coronary atherosclerosis [16]. It is essential in prevention of lethal murine pancreas ischemia reperfusion injury [17]. BH4 reduces tissue injury following ischemia-reperfusion injury after kidney, liver, lung and heart transplantation [18]. In addition, BH4 can reverse inflammation-induced impairment of the endothelium [19]. However, in pathological states in which BH4 bioavailability is reduced (e.g., oxidized by increased levels of free radicals, such as superoxide and peroxynitrite), NOS becomes dysfunctional and its activity "uncoupled" to favor superoxide production. This imbalance in $\mathrm{NO} /$ superoxide production results in oxidative stress, a major contributing factor in a variety of vascular dysfunction associated with hypertension, ischaemic reperfusion injury and diabetes [9]. The interest in the role of $\mathrm{BH} 4$ continues to grow. Therefore, the present study was designed to study the effect(s) of $\mathrm{BH} 4$ on the acute pancreatic damage induced by cadmium and demonstrate the possible mechanism(s) of its action. 


\section{MATERIALS AND METHODS}

\section{Experimental animals}

A total number of thirty adult (about twelve-weeks old) male albino rats weighing 140-180 g were obtained and maintained in Animal house of Faculty of Medicine, Assuit University. They were kept in well ventilated room at temperature of $\left(23 \pm 3^{\circ} \mathrm{C}\right)$ under natural light/dark cycle and were allowed free access to standard rat chow and water. The experimental procedures were carried out according to Guidelines of Care and Use of Laboratory Animals and approved by Ethical Committee at Faculty of Medicine, Assiut University, Egypt.

Chemicals

(6R)-5, 6, 7, 8-Tetrahydrobiopterin dihydrochloride $\left(\mathrm{BH}_{4}\right)$ and cadmium chloride $\left(\mathrm{CdCl}_{2}\right)$ were purchased from Sigma-Aldrich Co., St. Louis, MO, USA.

\section{Experimental Design}

Rats were randomly divided into three equal experimental groups (10 rats each). Control group: were given $1 \mathrm{ml}$ of normal saline $(0.9 \% \mathrm{NaCl})$ injected intra-peritoneal (i.p.). Cadmium-treated group (Cd): received single dose of $4 \mathrm{mg} / \mathrm{kg}$ body weight of $\mathrm{CdCl}_{2}$ [20] which was dissolved in normal saline and injected i.p. into the rats. $\mathrm{BH} 4+\mathrm{Cd}-$ treated group $(\mathrm{BH} 4+\mathrm{Cd})$ : received single dose of BH4 (20 mg/kg, i.p.) [21] and subsequently exposed to single dose of $\mathrm{CdCl}_{2}$ (4 $\mathrm{mg} / \mathrm{kg}$, i.p.) one hour after the $\mathrm{BH} 4$ treatment.

\section{Collection of samples and biochemical Analysis}

After $24 \mathrm{~h}$ from $\mathrm{Cd}$ exposure, $2 \mathrm{ml}$ blood were collected in glass tubes from orbital sinus and whole blood was centrifuged after clotting, and the serum was separated and the samples were maintained at $-20{ }^{\circ} \mathrm{C}$ until used. The animals were sacrificed, then the pancreas was obtained from each animal, part was stored at $-80^{\circ} \mathrm{C}$ for subsequent biochemical analysis and the other part fixed with $10 \%$ formalin phosphate and processed for haematoxylin and eosin (H\&E) staining for histological examination.

\section{a- Estimation of biochemical parameters in the serum}

Serum $\alpha$-amylase and lipase were measured by colorimetric enzyme assay kits (Lab-Care Diagnostics, INDIA). Serum glucose level was determined using the colorimetric analysis (Abcam, Cambridge, MA, United States). Ultrasensitive rat-specific ELISA kit (Crystal Chem, USA) was used for insulin assay. Serum IL-6 was measured by (BioSource International, Camarillo, California, USA).

\section{b-Biochemical parameters in pancreatic tissue}

Part of the frozen pancreatic tissues was homogenized in $50 \mathrm{mM}$ phosphate buffer ( $\mathrm{pH}$ 7.4) by means of a homogenizator (Heidolph Diax 900; Heidolph Elektro GmbH, Kelheim, Germany) on an ice cube. The homogenates were centrifuged at $7530 \mathrm{~g}$ in $4{ }^{\circ} \mathrm{C}$ for $10 \mathrm{~min}$. The supernatant of tissue homogenate was used for determination of: 1) The presence of MDA, a biomarker of lipid peroxidation by the method described by AlFawaeir et al. [22]. 2) SOD activity as previously described by Aydin et al. [23]. The results were expressed in relation to the protein content. 3) The other part of the frozen pancreatic tissues was taken and homogenized with ICAM-1 reaction buffer supplied with the kit. The supernatants obtained after centrifugation were used to determine ICAM-1 using a rat ELISA Kit (Bosde 
Biotechnology, Wuhan, China). Protein content of the supernatants was determined using Lowry et al. [24] method.

\section{Histopathological examination}

Pancreatic tissues were fixed with $10 \%$ neutral formalin phosphate buffer, dehydrated through a graded alcohol series and embedded in paraffin, then were cut into 5-7 $\mu \mathrm{m}$ sections and stained with haematoxylin and eosin according to Drury and Wallington [25]. The sections were examined under light microscopy.

\section{Statistical analysis}

Statistical analysis was performed using the GraphPad Prism software version 3 (GraphPad Software, San Diego California, USA). The results were presented in the form of mean \pm standard deviation (SD) for ten rats in each experimental group. One way analysis of variance (ANOVA) with Bonferroni Multiple Comparison test was done to compare between the studied groups. Pvalues $<0.05$ were considered as significant.

\section{RESULTS}

\section{1-Biochemical markers in serum}

The levels of serum amylase and lipase enzymes were significantly increased in cadmium treated compared to the control group ( $\mathrm{P}<0.001$ for each). However, in $\mathrm{BH} 4+\mathrm{Cd}$ group there are significant lower levels of amylase and lipase versus $\mathrm{Cd}$ group (for amylase $\mathrm{P}<0.01$ and for lipase $\mathrm{P}<0.05$ ). Comparing to control amylase and lipase enzymes were still significantly higher $(\mathrm{P}<0.05$ for each) in BH4+Cd group (Table 1).

Serum level of glucose was significantly increased in $\mathrm{Cd}$ group as compared to the control group $(\mathrm{P}<0.001)$. Treatment with $\mathrm{BH} 4$ in $\mathrm{BH} 4+\mathrm{Cd}$ group lead to significant lower level of glucose as compared to $\mathrm{Cd}$ group $(\mathrm{P}<0.01)$. There was nonsignificant change in glucose level in $\mathrm{BH} 4+\mathrm{Cd}$ group when compared with control (Table1).

Table 1: Serum levels of $\alpha$-amylase, lipase, glucose and insulin in the studied groups.

\begin{tabular}{lccc}
\hline & $\begin{array}{c}\text { Control } \\
\mathbf{n = 1 0}\end{array}$ & $\begin{array}{c}\mathbf{C d} \\
\mathbf{n}=\mathbf{1 0}\end{array}$ & $\begin{array}{c}\text { BH4+ Cd } \\
\mathbf{n}=\mathbf{1 0}\end{array}$ \\
\hline $\boldsymbol{\alpha}$-amylase (U/L) & $62.60 \pm 5.34$ & $76.2 \pm 3.19 * * *$ & $68.6 \pm 4.25 *, \# \#$ \\
Lipase (U/L) & $24.40 \pm 3.03$ & $29.8 \pm 1.54 * * *$ & $27.0 \pm 1.60 *, \#$ \\
Glucose (mmol/L) & $9.10 \pm 1.01$ & $11.6 \pm 1.20 * * *$ & $9.9 \pm 1.20 \mathrm{~ns}, \# \#$ \\
insulin (nmol/L) & $0.41 \pm 0.04$ & $0.31 \pm 0.04 * * *$ & $0.37 \pm 0.03 *, \# \#$ \\
\hline
\end{tabular}

Data are the mean \pm SD. $* \mathrm{P}<0.05, * * * \mathrm{P}<0.001$, ns: non significant as compared to control group.

${ }^{\#} \mathrm{P}<0.05$ and ${ }^{\# \#} \mathrm{P}<0.01$ as compared to Cd treated group. Cd: Cadmium chlorid, BH4: Tetrahydrobiopterin.

Regarding serum insulin level in different groups, cadmium-exposed group shows a significant reduction of insulin level versus control group $(\mathrm{P}<0.001)$. Of interest, $\mathrm{BH} 4$ treatment in $\mathrm{BH} 4+\mathrm{Cd}$ group caused a significant increase of the insulin level versus cadmium exposed group $(\mathrm{P}<0.01)$, but still there was a significant decrease of insulin hormone in comparing to control group $(\mathrm{P}<0.05)$ (Table 1). IL6 level of the Cd group was significantly increased when compared to the control $(\mathrm{P}<0.001)$. Co-adminstration of $\mathrm{BH} 4$ and cadmium in BH4+Cd group resulted in significant 
reduction of IL6 compared to Cd group ( $\mathrm{P}<0.01)$. IL6 level of BH4+Cd group was significantly increased as compared to control $(\mathrm{P}<0.05)$ (Fig 2 b).

\section{2-Biochemical markers in pancreatic tissue}

\section{homogenate}

According to (Fig $1 \mathrm{a}, \mathrm{b}$ ) which demonstrated that in pancreatic tissue homogenate MDA was significantly increased $(\mathrm{P}<0.01)$ and $\mathrm{SOD}$ was significantly decreased $(\mathrm{P}<0.01)$ in cadmium treated group compared to the control group. Treatment with $\mathrm{BH} 4$ in group III resulted in a significant lower level of MDA $(\mathrm{P}<0.05)$ and a significant higher level of SOD $(\mathrm{P}<0.05)$ as compared to Cd group. There were normalization of both MDA and SOD in pancreatic tissue homogenate as compared to control.
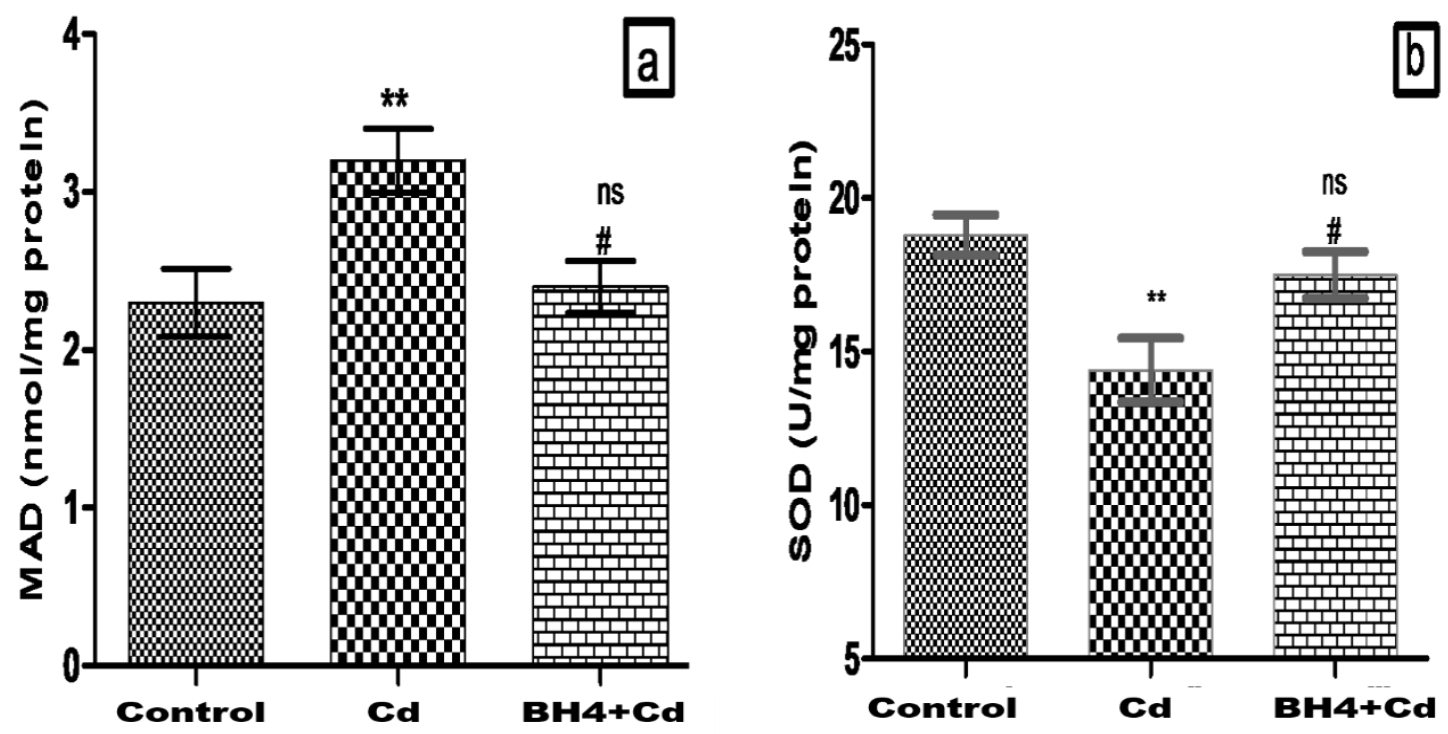

Fig.1. Levels of a: MDA (nmol/mg protein) and b: SOD (U/mg protein) in pancreatic tissue homogenate of the studied groups. ** $\mathrm{P}<0.01$, ns: non significant, as compared to group I. $\# \mathrm{P}<0.05$ as compared to group II. MDA: malondialdehyde. SOD: superoxide dismutase
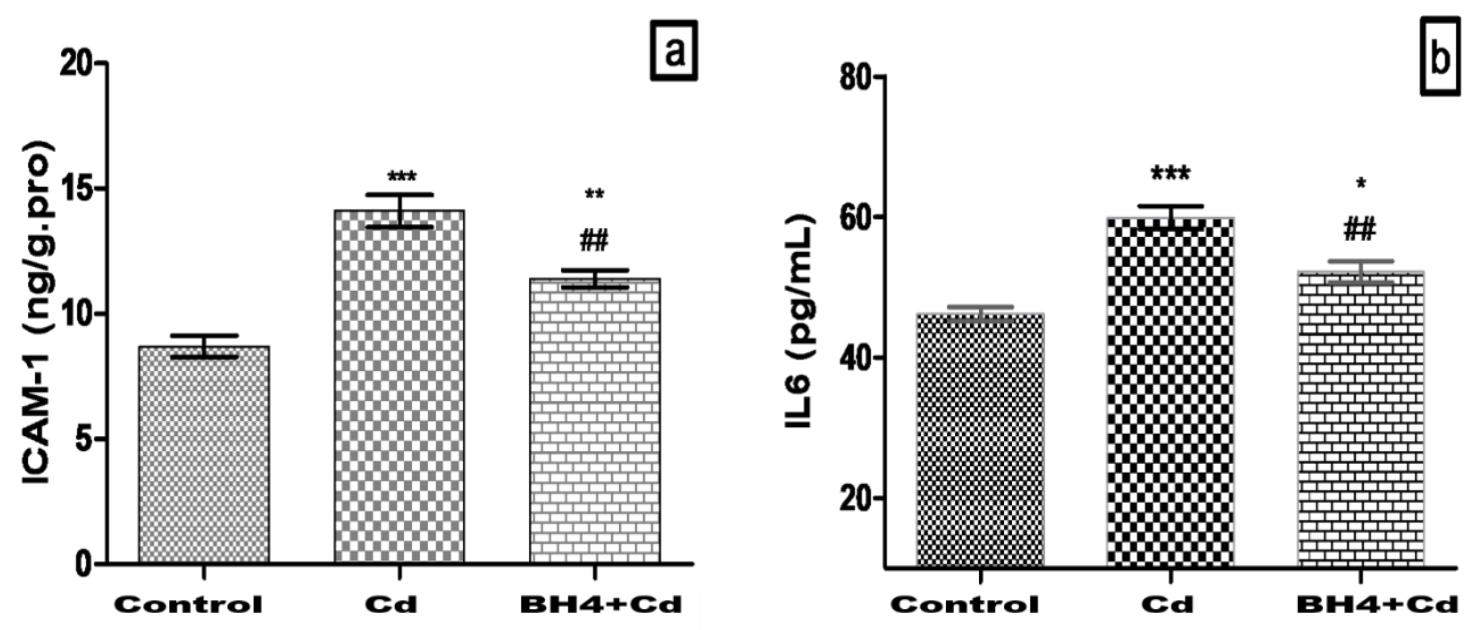

Fig. 2. Levels of a: ICAM-1(ng/g.pro) in pancreatic tissue homogenate and b: IL6 (pg/mL) in serum of the studied groups. * $\mathrm{P}<0.05$, ** $\mathrm{P}<0.01$, *** $\mathrm{P}<0.001$, as compared to group I. \#\# $\mathrm{P}<0.01$ as compared to group II. ICAM-1: intercellular adhesion molecular-1. IL 6: interleukin 6 
The level of ICAM-1 in pancreatic tissue homogenate was significantly increased in cadmium treated ( $\mathrm{Cd}$ group) compared to the control group $(\mathrm{P}<0.001)$. However, $\mathrm{BH} 4+\mathrm{Cd}$ group had a significant lower level of ICAM-1 in pancreatic tissue versus $\mathrm{Cd}$ treated group $(\mathrm{P}<$ 0.01). Comparing to control ICAM-1 in pancreatic tissue homogenate was still significantly higher $(\mathrm{P}<0.01)$ in $\mathrm{BH} 4+\mathrm{Cd}$ group (Fig $2 \mathrm{a})$.

\section{3-Histopathological results}

\section{Control group:}

The pancreas of control animal shows islets of Langerhans surrounded by many serous acini with very small lumens. The interlobular ducts lined by columnar epithelia. Cells of the islets of Langerhans are clumped masses of polygonal or rounded, smaller and more lightly stained than the surrounding acinar cells, arranged in cords separated by capillaries. The acinar cells of the acini are columnar containing basal nuclei. The supranuclear and apical cytoplasmic spaces are packed with secretory granules. Their nuclei are large and lightly stained. The basal regions of the gland cells are stained blue-violet (Fig 3 a).

\section{Cd group:}

The pancreas of $\mathrm{Cd}$ treated animal shows disturbed acinar pattern with narrow acinar lumen indicating little amount of secretion. Cellular infiltrations between the acini are clearly obvious. The islets of Langerhans cells show pale stained nuclei (lighter than control). Dilated capillaries between the islets cells are clearly obvious (Fig 3 b).

\section{BH4+Cd group:}

The pancreas of $\mathrm{BH} 4$ and $\mathrm{Cd}$ treated group shows acini more or less similar to the control. Cellular infiltrations are little. The islets of Langerhans cells showed pale stained nuclei (lighter than control). Dilated capillaries between the islets cells are clearly obvious but less than that of $\mathrm{Cd}$ treated alone (Fig $3 \mathrm{c}$ ).

\section{DISCUSSION}

The present study showed significant increase in the serum levels of $\alpha$-amylase, lipase and glucose and significant decrease in serum insulin level following cadmium administration compared to the control group indicating pancreatic damage. These findings is consistent with Khorasgani et al. [26] who found that cadmium had exerted a toxic effect on pancreatic tissue which lead to extrusion of pancreatic lipase and amylase into the plasma. Lei et al. [27] found that $\mathrm{Cd}$ affects carbohydrate metabolism by injuring the Langerhans islet beta cells and reducing insulin secretion leads to hyperglycemia.

The present data revealed that $\mathrm{BH} 4$ administration decreased significantly the levels of $\alpha$-amylase and lipase and glucose and increased significantly insulin level. These findings support those of Sugiyama et al. [28] who showed that the increases in the serum amylase level were significantly attenuated by the administration of BH4. Abudukadier et al. [21] demonstrated that BH4 has a glucose-lowering effect by suppressing hepatic gluconeogenesis in an endothelial nitric oxide synthase dependent manner and ameliorates glucose intolerance as well as insulin resistance in diabetic mice 

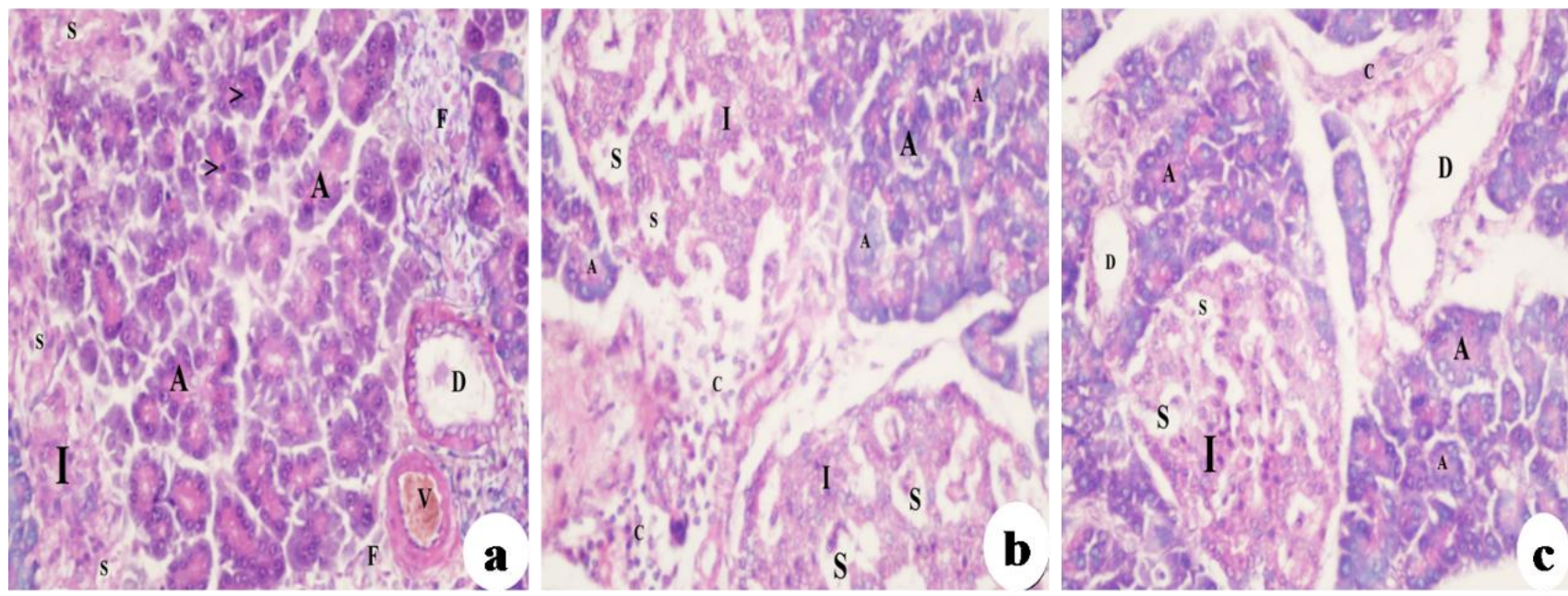

Fig. 3. Representative photograph of rat's pancreas of: (a) Control group showed islets of Langerhans (I) surrounded by many serous acini (A). The centroacinar cells (arrow head)inserted into the acinar lumen. The interlobular ducts (D) lined by columnar epithelia. Cells of the islets of Langerhans arranged in cords separated by fenestrated capillaries (S). The acini are surrounded by connective tissue with fibroblasts (F). The ducts and blood vessels (V) are located in connective tissue. (b)Cd groupshowed that the acini are disturbed in shape with narrower acinar lumen. Cellular infiltrations (C) and dilated capillaries between the islets (S) cells are clearly obvious. (c)BH4+Cdgroup showed that the acini are more or less similar to the control. Cellular infiltrations (C) are little. Dilated capillaries between the islets (S) cells are cells are clearly obvious but less than that of Cd treated alone.

Attention was drawn to the role of oxygen radicals and inflammatory mediators in acute pancreatitis [29]. The release of reactive oxygen species in acute pancreatitis might induce autodigestion of acinar cells [30] and pancreatic necrosis which triggers activation of inflammatory cells [31] leading to the production of proinflammatory cytokines, such as interleukin IL 6 [32]. The results of this study confirm and extend the finding of these studies. The current study has displayed a significant increase in the level of MDA a biomarker of lipid peroxidation and an inhibition of SOD involved in antioxidant defense mechanism against free radicals generated following exposure to cadmium in pancreatic tissue homogenate. These results corroborate with Erdogan et al. [33] who observed the same effect of cadmium on MDA and SOD. Also, Olalekan Lawal et al. [34] observed that cadmium induces oxidative stress. It has been documented that $\mathrm{Cd}$ - induced toxic effects are associated with the production of ROS, which can destroy DNA, proteins, and lipid function, and activate signaling pathways that cause cell death [35]. Pancreatic $\beta$ cells are at greater risk of apoptosis due to ROS attack than other cell types. The mitochondria of $\beta$ -cells can generate excessive levels of ROS. They are the major source of ROS in these cells and also a primary target for ROS attack. This, combined with a failure of the ROS defense system, results in the relatively high vulnerability of $\beta$-cells to oxidative stress damage [36]. Zhang et al. [37] stated that when SOD and GSH levels drop, the antioxidant capabilities of the pancreas are also reduced.

However, the present study revealed that the increment of MDA and decrement of SOD were normalized with $\mathrm{BH} 4$ administration suggesting that $\mathrm{BH} 4$ may exhibit its preventive effect against cadmium toxicity by enhancing the antioxidant enzyme probably through its free radical scavenging activity. These results concur with the 
studies of Ishii et al. [38] who found that BH4 may act as a scavenger of ROS, and may protect $\beta$-cells against ROS. Also, Kojima et al. [39] showed that BPH4 inhibited the elevation of lipid peroxides and had extremely strong superoxide anion radical-scavenging activity. Moreover, VásquezVivar et al. [40] explained the antioxidant effects of $\mathrm{BH} 4$ in the vasculature by inhibition of superoxide formation from eNOS due to a superoxide scavenging activity of $\mathrm{BH} 4$.

The present study showed a significant increased in the level of IL6 and ICAM-1 and disturbed acinar pattern with cellular infiltration between the acini after exposure to cadmium as compared with the control. This observation agrees with CormetBoyaka et al. [41] who demonstrated that cadmium treatment induced significant increase in IL-6 and Jiang et al. [42] who reported that $\mathrm{Cd}$ increase ICAM-1 expression in renal proximal tubule. Interleukin-6 is an important mediator during inflammatory response, as a part of acute reaction and inducing ICAM-1 expression which regulates neutrophil adhesion [43]. Also, Oxygen free radicals can stimulate the expression of ICAM-1 in the acute pancreatitis and accelerate inflammatory cell infiltration in the pancreas [44]. Zaninovic et al. [45] stated that ICAM-1 is upregulated in pancreas of rats with experimental pancreatitis.

In the current study, investigations emphasized that $\mathrm{BH} 4$ treatment significantly decreased the IL6 and ICAM-1 and the acini became more or less similar to the control. These data suggest that BH4 and can effectively suppress the inflammatory damage caused by cadmium in the pancreas. These results concur with Korish and
Arafah [46] who observed that $\mathrm{BH} 4$ can decrease the production of the inflammatory markers as Creactive protein and IL-6. Also, Elio et al. [47] reported that $\mathrm{BH}_{4}$ treatment attenuates polymorphonuclear neutrophil vascular adherence and tissue infiltration, by inhibiting ICAM-1 expression.

In conclusion, BH4 induced improvements in pancreatic tissue and functions in cadmiumexposed rats. It significantly restores serum amylase, lipase, glucose, insulin levels and ameliorates the disturbed pancreatic tissues. Since cadmium exposure is followed by tissue oxidative stress and inflammation, part of $\mathrm{BH} 4$ beneficial effects could be attributed to anti-oxidative and anti-inflammatory activity.

\section{Acknowledgments}

We would like to thank Dr. Ashraf H. Abd ELHakeem, Professor of Human Anatomy and Embryology, Faculty of Medicine, Assiut University, Egypt for his kind help in histological assessments.

\section{REFERENCES}

1. Goyer RA, Clarkson TW: Toxic effects of metals. In: Casarett and Doull's toxicology: the basic science of poisons. LJ Casarett, J Doull, CD Klaassen, (eds), McGraw-Hill, New York, 2001, pp 811-867.

\section{Nordberg GF, Nogawa $K$, Nordberg $M$,} Friberg L: Cadmium. In: Handbook on the Toxicology of Metals. GF Nordberg, GF Fowler, M Nordberg, L Friberg (eds), Elsevier, Amsterdam, 2007, pp 445-486. 
3. Haouem S, El Hani A: Effect of cadmium on lipid peroxidation and on some antioxidants in the liver, kidneys and testes of rats given diet containing cadmium-polluted radish bulbs. J Toxicol Pathol 26 (4):359-64, 2013.

4. Lei LJ, Jin TY, Zhou YF: The toxic effects of cadmium on pancreas. Zhonghua Lao Dong Wei Sheng Zhi Ye Bing Za Zhi 23 (1): 45-9, 2005.

5. Kanter, M, Yoruk M, Koc A, Meral I, Karaca T: Effects of cadmium exposure on morphological aspects of pancreas, weights of fetus and placenta in streptozotocin-induced diabetic pregnant rats. Biol Trace Elem Res 93(1-3): 189-200, 2003.

6. Fisic E, Poropat G, Bilic-Zulle L, Licul V, Milic S, StimacD: The role of IL6, 8, and 10, sTNFr, CRP, and pancr eatic elastase inthe prediction of systemic compli catios in patients with acute pancreatitis. Gastroenterol Res Pract 2013:282645, 2013.

7. Shagirtha K, Muthumani M, and Prabu S M: Melatonin abrogates cadmium induced oxidative stress related neurotoxicity in rats. European Review for Medical and Pharmacological Sciences 15(9): 1039-1050, 2011.

8. Yamano T, DeCicco LA, Rikans LE: Attenuation of cadmium-induced liver injury in senescent male fischer 344 rats: role of Kupffer cells and inflammatory cytokines. Toxicol Appl Pharmacol 162: 68-75, 2000.

9. Werner ER, Blau N, Thöny B: Tetrahydrobiopterin: biochemistry and pathophysiology. Biochem J 15;438(3):397-414, 2011.

10. Thöny B, Auerbach G, Blau N: Tetrahydrobiopterin biosynthesis, regeneration and functions. Biochem J 1;347 (1):1-16, 2000.
11. Schmidt PP, Lange R, Gorren AC, Werner ER, Mayer B, Andersson KK: Formation of a protonated trihydrobiopterin radical cation in the first reaction cycle of neuronal and endothelial nitric oxide synthase detected by electron paramagnetic resonance spectroscopy. J BiolInorgChem 6: 151, 2001.

12. Watschinger K, Keller MA, Golderer G, Hermann M, Maglione M, Sarg B, Lindner HH, Hermetter A, Werner-Felmayer G,. Konrat R, Hulo N, Werner ER: Identification of the gene encoding alkylglycerol monooxygenase defines a third class of tetrahydrobiopterin-dependent enzymes. Proc Natl Acad Sci U S A 107: 13672, 2010.

\section{Bendall JK, Douglas G, McNeill E, Channon}

KM, Crabtree MJ: Tetrahydrobiopterin in cardiovascular health and disease. Antioxid Redox Signal 20(18):3040-77, 2014.

\section{Stroes E, Kastelein J, Cosentino F, Erkelens} W, Wever R, Koomans H, Luscher T, Rabelink T: Tetrahydrobiopterin restores endothelial function in hypercholesterolemia. $\mathrm{J}$ Clin Invest 99: 41-46, 1997.

15. Heitzer T, Krohn K, Albers S, Meinertz T: Tetrahydrobiopterin improves endotheliumdependent vasodilation by increasing nitric oxide activity in patients with Type II diabetes mellitus. Diabetologia 43: 1435-1438, 2000.

16. Maier W, Cosentino F, Lutolf R B, Fleisch $M$, Seiler C, Hess O M, Meier B, Luscher T F: Tetrahydrobiopterin improves endothelial function in patients with coronary artery disease. J Cardiovasc Pharmacol 35: 173-178, 2000.

17. Maglione $\mathbf{M}$, Cardini B, Oberhuber R, Watschinger K, Jenny M, Gostner J, Hermann M, Obrist P, Margreiter R, 
Pratschke J, Brandacher G, Werner ER: Prevention of lethal murine pancreas ischemia reperfusion injury is specific for tetrahydrobiopterin. Transpl Int 25(10):1084-95, 2012.

18. Hara Y, Teramoto K, Kumashiro Y, Sato E, Nakamura N, Takatsu S, Kawamura T, Arii S: Beneficial effect of tetrahydrobiopterin on the survival of rats exposed to hepatic ischemiareperfusion injury. Transplant Proc 37: 442-444, 2005.

19. Mittermayer F, Pleiner J, Schaller G, Zorn S: Tetrahydrobiopterin corrects Escherichia coli endotoxin-induced endothelial dysfunction. Am J Physiol Heart Circ Physiol 289: H1752-H1757, 2005.

20. Fernández EL, Gustafson AL, Andersson M, Hellman B, Dencker L: Cadmium-induced changes in apoptotic gene expression levels and DNA damage in mouse embryos are blocked by zinc. Toxicol Sci. 76(1):162-70, 2003.

21. Abudukadier A, Fujita Y, Obara A, Ohashi

$\begin{array}{lcr}\text { A, Fukushima } & \text { T, Sato } & \text { Y, Ogura } \\ \text { M, Nakamura } & \text { Y, Fujimoto } & \text { S, Hosokawa } \\ \text { M, Hasegawa } & \text { H, Inagaki } & \text { N: }\end{array}$

Tetrahydrobiopterin has a glucose-lowering effect by suppressing hepatic gluconeogenesis in an endothelial nitric oxide synthase-dependent manner in diabetic mice. Diabetes 62(9):303343, 2013.

22. Al-Fawaeir S, Akgul EO, Cayci T, Demirin H, Gülcan Kurt Y, Aydın İ, Ağıllı M, Özkan E, Yaman H, Çakır E, Kemal Erbil M: Comparison of two methods for malondialdehyde measurement. J Clin Anal Med 2: 11-14, 2011.
23. Aydin A, Orhan H, Sayal A, Ozata M, Sahin G, Işimer A: Oxidative stress and nitric oxide related parameters in type II diabetes mellitus: effects of glycemic control. Clin Biochem 34(1): 65-70, 2001.

\section{Lowry OH, Rosebrugh NJ, Farr AL, Randall}

RJ: Protein measurement with the Folin phenol reagent. J Biol Chem 193: 265-275, 1951.

25. Drury $\mathbf{R}$ A B, Wallington $\mathbf{E}$ A: Carleton's Histological Technique, 4th ed., Oxford University Press, London, New York, Toronto, 1980.

26. Khorasgani E M, Haghdoost I S, Sedaghat R, Mortazavi $P$ and Roghani M. Satureja hortensis L: Alcoholic Extract Ameliorates Cadmium-Induced Pancreatic Damage in Rats. Middle-East Journal of Scientific Research 15 (1): 32-35, 2013.

27. Lei LJ, Jin TY, Zhou YF: Effects of cadmium on levels of insulin in rats. Wei Sheng Yan Jiu 34(4):394-6, 2005.

28. Sugiyama Y, Kato S, Mitsufuji S, Okanoue T, Takeuchi K: Pathogenic role of endothelial nitric oxide synthase (eNOS/NOS-III) in cerulein-induced rat acute pancreatitis. Dig Dis Sci 51(8):1396-403, 2006.

29. Escobar J, Pereda J, Arduini A, Sandoval J, Sabater $\quad$ L, Aparisi $\quad$ L, López-Rodas G, Sastre J: Cross-talk between oxidative stress and pro-inflammatory cytokines in acute pancreatitis: a key role for protein phosphatases. Curr Pharm 15(26):3027-42, 2009.

30. Apte MV, Pirola RC, Wilson JS: Molecular mechanisms of alcoholic pancreatitis. Dig Dis 23:232-40, 2005.

31. Weber CK, Adler G: From acinar cell damage to systemic inflammatory response: current 
concepts in pancreatitis. Pancreatology 1:356-62, 2001.

32. Akay C, Yaman H, Oztosun M, Cakir E, Yildirim AO, Eyi YE, Agilli M, Akgul EO, Aydin I, Kaldirim U, Tuncer SK, Eken A, Oztas E, Poyrazoglu Y, Yasar M, Ozkan Y: The protective effects of taurine on experimental acute pancreatitis in rat model. Hum Exp Toxicol 32(5):522-9, 2013.

33. Erdogan Z, Erdogan S, Celik S, Unlu A: Effects of ascorbic acid on cadmium-induced oxidative stress and performance of broilers. Biol Trace Elem Res. 104(1):19-32, 2005.

34. Olalekan Lawal A, Lawal AF, Ologundudu A, Adeniran OY, Omonkhua A, Obi F : Antioxidant effects of heated garlic juice on cadmium-induced liver damage in rats as compared to ascorbic acid. J Toxicol Sci 36(5):549-57, 2011.

35. Kim SC, Byun SH, Yang CH, Kim CY, Kim JW, Kim SG: Cytoprotective effects of Glycyrrhizae radix extract and its active component liquiritigenin against cadmiuminduced toxicity (effects on bad translocation and cytochrome c-mediated PARP cleavage). Toxicology 197:239-251, 2004.

36. Kaneto H, Kawamori D, Matsuoka TA, Kajimoto Y, Yamasaki Y: Oxidative stress and pancreatic beta-cell dysfunction. Am J Ther 12: 529-533, (2005).

37. Zhang DQ, Feng H, Chen WC: Effects of hydrogen- rich saline on taurocholateinduced acute pancreatitis in rat. Evid Based Complement Alternat Med 2013:731932, 2013.

38. Ishii M, Shimizu S, Watabe T, Kiuchi Y: Insulin Secretion in Response to L-Arginine under Decreasing Tetrahydrobiopterin Content Pteridines 19(4): 93-100, 2008

39. Kojima S, Ona S, Iizuka I, Arai T, Mori H, Kubota K:

Antioxidative activity of 5,6,7,8tetrahydrobiopter in andits inhibitory effect on paraquat-

nducedcell toxicity in cultured rat hepatocytes. Free Radic Res 23(5):419-30, 1995.

40. Vásquez-Vivar J, Whitsett J, Martásek P, Hogg N, Kalyanaraman B: Reaction of tetrahydrobiopterin with superoxide: EPR-kinetic analysis and characterization of the pteridine radical. Free Radic Biol Med 31(8):975-85, 2001.

41. Cormet-Boyaka E, Jolivette K, BonnegardeBernard A, Rennolds J,Hassan F, Mehta P, Tridandapani S, Webster-Marketon J, Boyaka PN: An NF- $\kappa B-i n d e p e n d e n t$ and Erk1/2-dependent mechanism controls CXCL8/IL-8 responses of airway epithelial cells to cadmium. Toxicol Sci 125: 418-429, 2012.

42. Jiang J, McCool BA, Parrish AR: Cadmiumand mercury induced intercellular adhesion molecule-1 expression in immortalized proximal tubule cells: evidence for a role of decreased transforming growth factor-beta1. Toxicol Appl Pharmacol 179: 13-20, 2002.

43. Gregoric P, Sijacki A, Stankovic S, Radenkovic D, Ivancevic N, Karamarkovic A, Popovic N, Karadzic B, Stijak L, Stefanovic B, Milosevic Z, Bajec D: SIRS score on admission and initial concentration of IL-6 as severe acute pancreatitis outcome predictors. Hepatogastroenterology 57(98): 349-353, 2010.

44. Granell S, Serrano-Mollar A, Folch-Puy E, Navajas D, Farre R, Bulbena O, Closa D: 
Oxygen in the alveolar air space mediates lung inflammation in acute pancreatitis. Free Radic Biol Med 37:1640-1647, 2004.

45. Zaninovic V, Gukovskaya AS, Gukovsky I, Mouria M, Pandol SJ: Cerulein upregulates ICAM-1 in pancreatic acinar cells, which mediates neutrophil adhesion to these cells. Am J Physiol Gastrointest Liver Physiol 279(4):G66676, 2000.

46. Korish AA, Arafah MM: The potential antiinflammatory effect of tetrahydrobiopetrin administration in renal mass reduction -induced chronic renal failure in rats. Saudi Med J. 28(12):1803-9, 2007.

47. Elio K, Jung Kim E E, Chen Q, Kay H Y, Adams J, Young L H: Tetrahydrobiopterin (BH4) attenuates neutrophil adhesion/transmigration in myocardial ischemia/reperfusion injury. The FASEB Journal 21:869.17, 2007. 


\section{الملخص العربى}

الآثار الوقائية المحتملة للتيتراهياروبيوبيترن على تغيرات البنكرياس الناتجة عن الكادميوم في ذكور الجرذان

إبتهال أنور عبد العزيز و نشوى على عبد المطلب

قسم الفسيولوجيا الطبية ، كلية الطب ، جامعة أسيوط

بعتبر الكادميوم من الملوثات البيئية و الصناعية على نطاق و اسع. فإنه يتر اكم في البنكرياس ويمكن أن يؤثر على وظائفه. تبتر اهيدروبيوبيترن ضروري لمختلف العمليات، وموجود في جميع أنسجة الكائنات الارقى. وقد صممت هذه الار اسة لبحث تأثير تيتر اهيدروبيوبيترن على الضرر الحاد للبنكرياس الناجم

عن الكادميوم و آلية عمله. نم تقسيم ثناثين جرذ بشكل عشو ائي إلى ثلاث مجموعات (10جرذان لكل منها). المجموعة الضابطة: اعطيت محلول ملح حقنا داخل البرونون و مجمو عة الكادميوم: اعطيت (جرعة واحدة 4 ملجم / كجم كادميوم كلور ايد، حقا داخل البرونون) ومجموعة تيتر اهيدروبيوبيترن + الكادميوم: تلقت (جر عة واحدة من تيتر اهيدروبيوبيترن 20ملجم / كجم، حقنا داخل البروتون قبل ساعة واحدة من جر عة الكادميوم كلور ايد الو احدة 4 ملجم / كجم ، حقنا داخل البرونون). تم قياس مستويات الفا الأميليز ، والليباز ، والجلوكوز و الأنسولين وانترلوكين -6 في مصل الام وقياس مستويات جزيء الالتصاق بين الخلايا- 1، مالونالدهايد وفوق اكسيد الديسميوتاز في كتلة البنكرياس المتجانسة. كما تم عمل فحص نسيجى للبنكرياس. قام تيتر اهيدروبيوبيترن بتحسين وظائف البنكرياس، حيث انخفضت مستويات الالفا الأمبليز، و اللبييز و الجلوكوز و انترلوكين- 6 انخفاضا ذو دلالة احصائية بينما زاد مستوى الأنسولين زيادة ذات دلالة احصائية في مصل الدم. قل ضرر البنكرياس كما يتضح من انخفاض مستويات جزيء الالتصاق بين الخلايا- 1 و المالونالدهايد وزيادة فوق اكسيد الديسميوتاز في كتلة البنكرياس المتجانسة. أيضا تحسنت أنسجة البنكرياس المتضررة. نستنتج أن تبتر اهيدروبيو بيترن أحدث تحسن في أنسجة البنكرياس ووظائفة في الجرذان المعرضة الكادميوم. ويمكن أن يعزى جزء من الآثار المفيدة للتبتر اهيدروبيوبيترن لنشاطه كمضاد للأكسدة ومضاد للالتهاب. 